\title{
Can credit quality as a moderating variable in increasing profitability: study on conventional commercial banks listed on the Indonesia stock exchange
}

\author{
Sriyono Sriyono ${ }^{1 *}$, Ana Nabellah ${ }^{2}$ \\ 1,2Management Study Program,University of Muhammadiyah Sidoarjo, Indonesia \\ *Corresponding email: sriyono@umsida.ac.id
}

\begin{tabular}{l} 
Article Info \\
\hline Article history: \\
Received : 11 July 2021 \\
Accepted: 8 October 2021 \\
Published: 1 January 2022 \\
\hline
\end{tabular}

JEL Classification Code: G41, H20

Author's email: ananabellah88@gmail.com

DOI: 10.20885/isb.vol26.iss1.art2

\begin{abstract}
Purpose: Increasing Profitability is necessary for a business so that business activities can still exist. Many previous studies have examined this matter. However, none have used credit quality as a moderating variable. This study aims to determine whether credit quality can be moderated to increase profitability.
\end{abstract}

Methodology: The population used is Conventional Commercial Bank Companies listed on the Indonesia Stock Exchange. The sample of this research is 80 conventional commercial bank companies listed on the Indonesia Stock Exchange. The sampling technique uses purposive sampling — data analysis using Partial Least Square with Smart PLS 3.0 software.

Finding: The result found a relationship between Capital Adequacy Level, Credit Distribution, Credit Quality, and Profitability. It showed that the level of capital adequacy has a positive effect on profitability. Credit quality cannot moderate the relationship between capital adequacy and lending to profitability.

Research limitation/Implication: This research was only conducted on conventional banks listed on the Indonesian stock exchange. The variables studied are only limited to financial factors

Practical Implication: The management will understand that the strategy to increase profitability does not require credit quality support through the research results. The use of moderating variables is expected to provide a new model for increasing profitability

Originality: In increasing profitability, the researcher offers a new model by using credit quality as a moderating variable.

Keywords: Capital Adequacy Level, Credit Distribution, Profitability, Credit Quality.

\section{Introduction}

The development of the banking sector has grown rapidly, which can dominate economic activities in Indonesia, namely in increasing development and economic growth in Indonesia. According to the Banking Act No. 10 of 1998 and the amendment of Law No. 7 of 1992 in article 1 paragraph (2) Banking Act, 1998, a Bank is a business entity that collects funds from the public in the form of savings and distributes them to them in the form of credit or other forms to improve the standard of living.

The development of banking in Indonesia as in Graph 1. From Graph 1, it can be explained that conventional and Islamic banking companies have very different profit growth. The graph above shows that conventional banks have higher profits than Islamic banks (in billion rupiahs). 


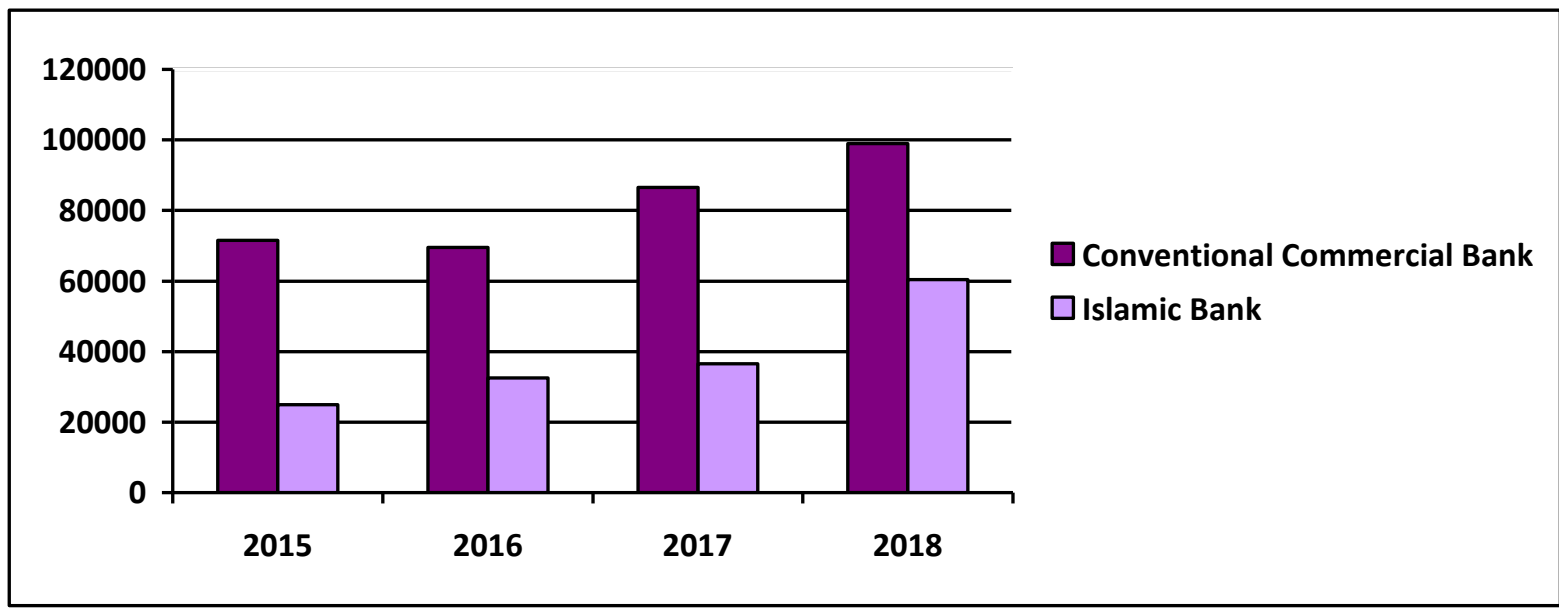

Source: Financial Services Authority (in billion)

Graph 1. Profit Growth of Conventional Banks and Islamic Banks

Thus, Conventional Commercial Banks are the prima donna of the most significant contribution to the Indonesian economy in terms of lending to the public compared to Islamic Commercial Banks. The research object in this study is an established general banking company listed on the Indonesia Stock Exchange (IDX).

The rapid development of the banking industry, especially conventional commercial banks, has led to competition that directly or indirectly affects bank profitability. This study uses several ratios that affect bank profitability, namely the Capital Adequacy Ratio, lending, and credit quality as moderating variables.

The company's main goal is to maximize profits and increase company value through assets or all owned capital (Saona, 2011). Therefore, the profitability ratio is the main measure of company performance. If a company can generate large profits with increasing profit growth over the years, it can say that it is good. The high level of profitability describes the good performance of a company, which means that the bank has been operating effectively and efficiently (Langodai \& Lutfillah, 2019).

However, obtaining high profitability or continuing to increase is not as easy as desired. This is because the difference between bank operating costs and income is not balanced (Najjar, 2013). The following are the profitability conditions of conventional commercial banks as follows:

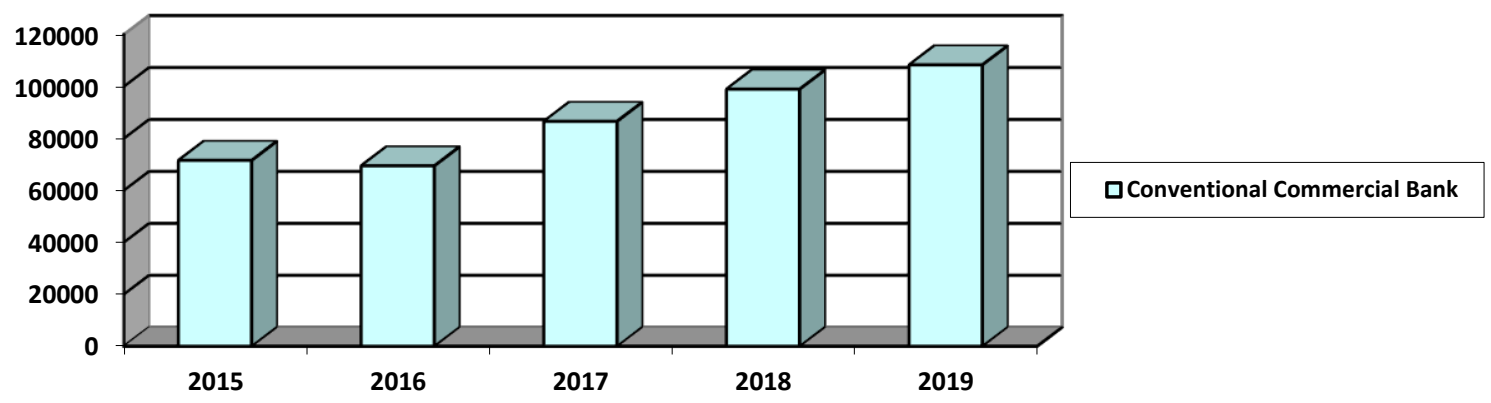

Source: Financial Services Authority (In billion)

Graph 2. Profit Growth of Conventional Banks and Islamic Banks

Capital adequacy (CAR) is one factor that plays an important role in a company's performance (Corcoran, 2010). Therefore, the adequacy of the Capital Adequacy Ratio is very important for a bank. A good Capital Adequacy Ratio will have good Profitability (Shingjergji \& Hyseni, 2015). With good bank capital requirements, the bank will be able to operate properly. (Eniola \& Ektebang, 2014). According to (Almazari, 2013) explains that capital adequacy affects profitability. Meanwhile, (Setiawan, 2017) explains that CAR does not affect profitability. 
Credit distribution is the main activity of banks in carrying out their operational activities. To is because the bank's main source of funding comes from its fund distribution activities. The greater the distribution of funds in the form of credit than deposits or public deposits in a bank, the greater the profitability income becomes (Suardita \& Putri, 2015). According to (Rengasamy, 2014), LDR has a positive effect on Profitability (ROA). Meanwhile, according to (Septiani \& Lestari, 2016), LDR has no significant positive effect on profitability.

Can credit quality moderate the relationship between the independent variable and the dependent variable? Research conducted by (Rinawati, 2019) explains that credit quality cannot moderate the relationship between capital and profitability. Research on credit quality was also carried out by (Nabellah, 2021), who explained that credit quality could moderate Operational Expenditure to Operating Income (BOPO). Research on credit quality is conducted in Indonesia and in foreign countries, such as China, which was conducted by (Ali et al., 2019), explaining that credit quality is used as a moderating variable of company performance.

With various research results showing that credit quality can moderate the company's performance and BOPO variables, the researcher uses the credit quality variable as a moderating variable of the relationship between capital adequacy and lending to profitability. To distinguish this research from previous research, the researcher applied a moderating variable of credit quality proxy for Non-Performing Loans (NPL).

The purpose of this study was to determine whether credit quality can moderate the relationship between the level of capital adequacy and lending to profitability. Research is significant because it provides important information for banks. The contribution of the research is substantial for banking management. Through the results of this research, banking management will easily understand how to Increase profitability.

\section{Literature Review and Hypothesis}

Capital adequacy is the ability of a bank in capital to cover possible losses in credit or securities trading. Profitability is the main goal of a company because it ensures the company's future. One of the ratios used to measure bank profitability is ROA. The higher the CAR achieved by the bank, the better the bank's performance and the bank's operations will run smoothly. Customer confidence in the bank increases so that the company's profitability will also increase; the company will benefit. Research conducted by (Olalekan \& Adeyinka, 2013; Madugu, et al, 2020; Faizah, Rahmawati Nur \& Saryadi, 2018; Bernardin, 2016) explains that the Capital Adequacy Ratio positively affects Return on Assets.

H0: Does Capital adequacy have a significant effect on profitability

H1: Capital adequacy has a significant effect on profitability

The level of lending or LDR (Loan Deposit Ratio) is the banks' ability in existing credit in providing funds to debtors with capital owned by the bank. LDR is the ratio used to measure the composition of the total credit. ROA is a ratio used to measure bank profitability. The greater the amount of credit disbursed by the bank, the profit on interest on loans obtained by the bank will also increase to affect the profitability obtained by the company. Research conducted by (Alshatti, 2015; Mismiwati, 2016; Santoso, 2016) explains that the level of lending (LDR) positively affects profitability.

H0: Does the Loan Deposit Ratio have no significant effect on profitability

H2: The Loan Deposit Ratio have a significant effect on profitability

The bank bears credit. Credit quality is the percentage of non-performing loans with criteria (loans in the current category, loans in the substandard category, loans in doubtful categories, and loans in the bad category) to the total loans disbursed by banks, the higher the quality of the loans, the smaller the risk. Non-performing loans (bad) increased due to lack of risk management, thus threatening bank profitability (Haneef et al., 2012). The capital adequacy level is a ratio that shows how far all bank assets that contain risks (credit and securities) are also financed from theirs- 
capital funds and obtaining funds from other sources. Research conducted by (Yusuf \& Surjaatmadja, 2018) explains that Credit Quality as a Moderating Variable cannot moderate the relationship between Capital Adequacy Ratio and Return on Assets.

In the world of banking, credit is the main element to make a profit. That means that the size of a bank's profit is strongly influenced by the amount of credit disbursed in a period. The more credit spent, the greater the profit (Berrios, 2013). If not on target, the high level of credit disbursement can lead to a greater risk of bad loans, so that it will affect the interest income received (Andika et al., 2018). (Ghosh, 2015) explained that credit quality cannot strengthen (weaken) the effect of the level of lending on Return on Assets.

H3: Enable credit quality as a moderating variable on the relationship between Capital adequacy, Loan Deposit Ratio on profitability

\section{Structure Equation Model}

$\mathrm{Y}=\beta_{0}+\beta_{1} \mathrm{X}_{1}+\beta_{2} \mathrm{X}_{2}+\beta_{3} \mathrm{X}_{3}+\mathrm{e}$

Notes:

$\mathrm{X}_{1}=$ Capital Adequacy Level

$\mathrm{X}_{2}=$ Credit Distribution

$\mathrm{X}_{3}=$ Credit Quality

$\mathrm{Y}=$ Profitability

$\mathrm{e}=$ error

\section{Research Method}

This research is quantitative research, given that it applied more numeric data in analyzing the facts found.

Table 1. Operational Definition, Variable Identification and Indicator Variable

\begin{tabular}{|c|c|c|c|}
\hline No & Variable & Indicator Variable & $\begin{array}{c}\text { Level of } \\
\text { Measurement }\end{array}$ \\
\hline 1 & $\begin{array}{l}\text { Capital Adequacy Level }\left(\mathrm{X}_{1}\right) \\
\text { (Harmono, 2017) }\end{array}$ & $\mathrm{CAR}=\frac{\text { Capital }}{\text { Total ATMR }} \times 100 \%$ & Ratio \\
\hline 2 & $\begin{array}{l}\text { Credit Distribution }\left(\mathrm{X}_{2}\right) \\
\text { (Taswan, 2013) }\end{array}$ & $\mathrm{LDR}=\frac{\text { Credit }}{\text { Third Party Funds }} \times 100 \%$ & Ratio \\
\hline 3 & $\begin{array}{l}\text { Profitability (Y) } \\
\text { (Harmono, 2017) }\end{array}$ & $\mathrm{ROA}=\frac{\text { Earning before Tax }}{\text { Total Assets }} \times 100 \%$ & Ratio \\
\hline 4 & $\begin{array}{l}\text { Credit Quality (Z) } \\
\text { (Taswan, 2013) }\end{array}$ & $\mathrm{NPL}=\frac{\text { Credit problems }}{\text { Total Credits }} \times 100 \%$ & Ratio \\
\hline
\end{tabular}

\section{Population and Sample}

The population used in this study is a conventional commercial bank listed on the Indonesia Stock Exchange. The sampling technique was purposive sampling.

Table 2. Sampling technique using purposive sampling

\begin{tabular}{ccc}
\hline No & Sampling Criteria & Company \\
\hline $1 \quad \begin{array}{l}\text { Conventional commercial banking companies listed on the Indonesia Stock Exchange } \\
\text { for the 2015-2018 period }\end{array}$ & 42 \\
$2 \quad$ Conventional general banking companies with profits including healthy criteria where & 20 \\
ROA $>1.22 \%$ during the 2015 period -2018 & 20 \\
Number of sample & 80 \\
Number of observations for four years $(20 \times 4)$ &
\end{tabular}


Therefore, based on the criteria from the sample, the number of the sample determined in this study was 80 conventional banks.

\section{Analysis Techniques}

Before the data is tested for the hypothesis, a descriptive statistical test was carried out, which aims to determine the condition of the data ((Sugiyono, 2016). The next step is the Outer Model Test which aims to test Convergent Validity, Discriminant Validity, Composite Reliability, and Multicollinearity. After that, the Inner Model test is carried out (Ghozali \& Latan, 2015). In the final stage, the hypothesis test is carried out using the t-test

\section{Results and Discussion}

Descriptive Statistics

Table 3. Test Results (Descriptive Statistics)

\begin{tabular}{lcccc}
\hline \multicolumn{1}{c}{ Indicators } & $\begin{array}{c}\text { Mean } \\
\text { (billion) }\end{array}$ & $\begin{array}{c}\text { Min } \\
\text { (billion) }\end{array}$ & $\begin{array}{c}\text { Max } \\
\text { (billion) }\end{array}$ & $\begin{array}{c}\text { Standard } \\
\text { Deviation }\end{array}$ \\
\hline level of adequacy of capital (X1) & 21620 & 14920 & 35120 & 4,101 \\
Loans (X2) & 89949 & 55350 & 145260 & 12049 \\
Profitability (Y) & 2267 & 1.3 & 4190 & 0802 \\
credit Quality (Z) & 2,403 & 0.510 & 4,770 & 0.941 \\
\hline
\end{tabular}

Testing Results Measurement Model (Outer Model)

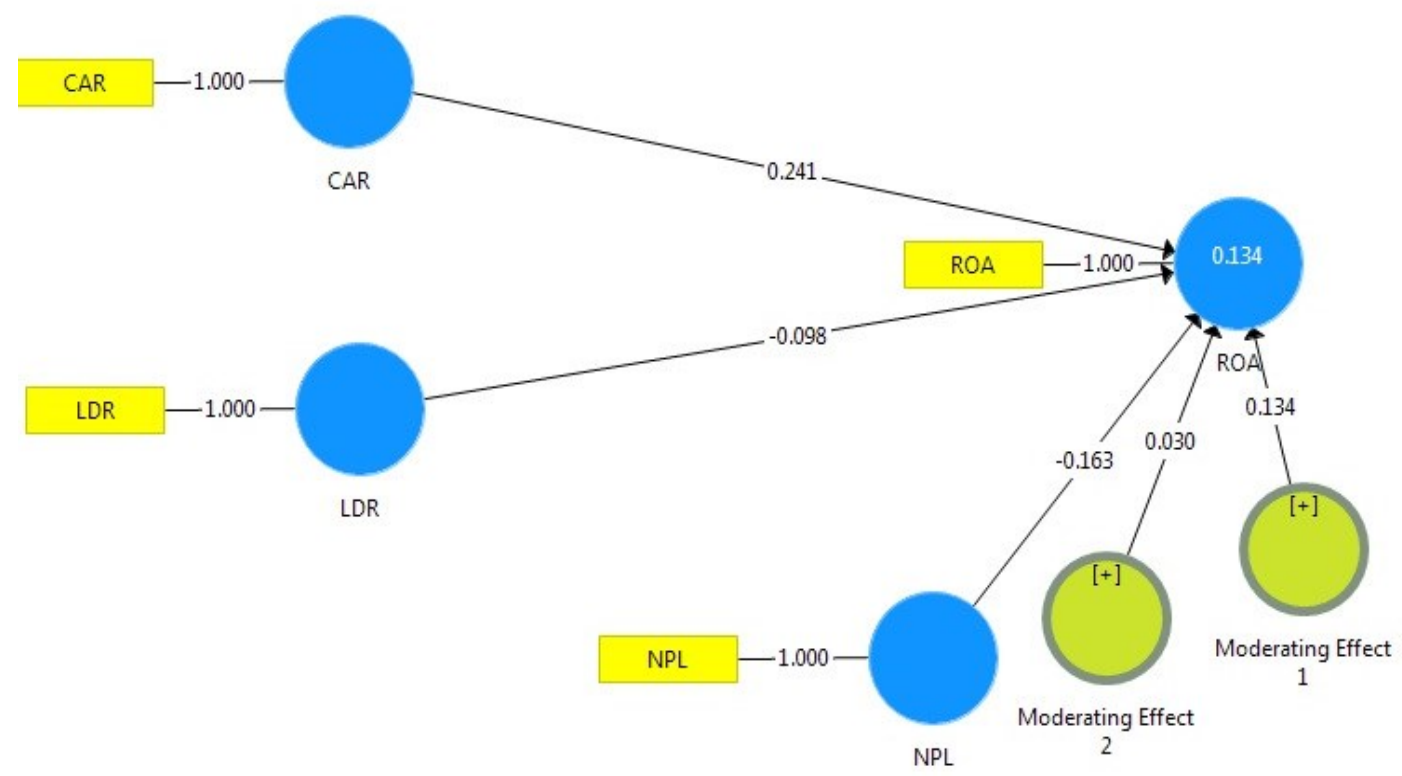

Figure 3. Retrieval of PLS Algorithm. Calculation Results

Table 4. Outer Loading Test Results

\begin{tabular}{lcccccc}
\hline & CAR & LDR & CAR * NPL & LDR * NPL & NPL & ROA \\
\hline $\mathrm{CAR}$ & 1,000 & & & & & \\
$\mathrm{CAR} * \mathrm{NPL}$ & & \multirow{2}{*}{0.882} & & & \\
$\mathrm{LDR}$ & & 1,000 & & 0.901 & & \\
$\mathrm{LDR} * \mathrm{NPL}$ & & & & & 1,000 & \\
$\mathrm{NPL}$ & & & & & 1,000 \\
$\mathrm{ROA}$ & & & & & & \\
\hline
\end{tabular}


The results of the convergent test validity in Table 4 show that all loading factor values are above 0.7. It means that the data used is valid for use in further research or has met the criteria.

Table 5. Test Results Average Variance Extracted

\begin{tabular}{c}
\hline Average Variance Extracted (AVE) \\
\hline 1,000 \\
1,000 \\
1,000 \\
1,000 \\
1,000 \\
1,000 \\
\hline
\end{tabular}

The AVE results in Table 5 show that all variables' AVE values have met convergent validity because all AVE values for each construct have met the criteria above 0.5.

Table 6. Test Results Discriminant Validity

\begin{tabular}{lcccccc}
\hline & CAR & LDR & Moderating Effect 1 & Moderating Effect 2 & NPL & ROA \\
\hline CAR & $\mathbf{1 , 0 0 0}$ & -0.208 & 0.271 & -0.193 & -0.070 & 0.299 \\
CAR*NPL & 0.271 & -0.197 & $\mathbf{1 , 0 0 0}$ & -0.273 & 0.101 & 0.179 \\
LDR & -0.208 & $\mathbf{1 , 0 0 0}$ & -0.197 & -0.128 & -0.119 & -0.156 \\
LDR*NPL & -0.193 & -0.128 & -0.273 & $\mathbf{1 , 0 0 0}$ & -0.083 & -0.025 \\
NPL & -0.070 & -0.119 & 0.101 & -0.083 & $\mathbf{1 , 0 0 0}$ & -0.159 \\
ROA & 0.299 & -0.156 & 0.179 & -0.025 & -0.159 & $\mathbf{1 , 0 0 0}$ \\
\hline
\end{tabular}

The cross-loading result in Table 6 shows that each latent variable indicator has a higher value than other constructs to fulfill the discriminant validity.

Table 7. Composite Reliability Values

\begin{tabular}{cc}
\hline Composite Reliability & Cronbach's Alpha \\
\hline 1000 & 1000 \\
1000 & 1000 \\
1000 & 1000 \\
1000 & 1000 \\
1000 & 1000 \\
1000 & 1000 \\
\hline
\end{tabular}

The reliability test results in Table 7 show that the Cronbach alpha and values composite reliability for each variable is above 0.70 ; it can be concluded that each construct variable is reliable or valid in this study.

Table 8. Multicollinearity Results of

\begin{tabular}{lc}
\hline \multicolumn{1}{c}{ Variable } & VIF \\
\hline Capital Adequacy Level (X1) & 1000 \\
Capital Adequacy Level * Credit QualityCredit & 1000 \\
Distribution (X2) & 1000 \\
Credit Distribution * Credit & 1000 \\
QualityCredit Quality (Z) & 1000 \\
Profitability (Y) & 1000 \\
\hline
\end{tabular}

The results of the test in Table 8 show that there is no multicollinearity between the independent variables. This can be seen from the VIF value $<5$ according to the recommended limit in the PLS. 


\section{Structural Model Testing Results (Inner Model)}

1. Testing Results The coefficient of determination(R2)

Table 9. Coefficient Determination Test Results

\begin{tabular}{ll}
\hline & R-Square \\
\hline Profitability & 0.134 \\
\hline
\end{tabular}

The R-Square value in Table 9 is 0.134 , which means that the construct of Capital Adequacy Level and Credit Distribution on Profitability with Credit Quality has a moderating variable of $13.4 \%$. The remaining $86.6 \%$ of other variables are not explained in this study.

2. Test Results Effect size

The effect size value obtained is 0.0369 , which indicates a small significant effect in this study. The moderation model used is the potential moderation model (Homologiser Moderator), which is meant by the potential moderation model, namely variables that have the potential or ability to become moderating variables but are not able to influence or be unable to moderate.

\section{Hypothesis Testing}

Table 10. Results ofAnalysishypothesis Test

\begin{tabular}{lccccc}
\hline & $\begin{array}{c}\text { SampleOriginal } \\
(\mathrm{O})\end{array}$ & $\begin{array}{c}\text { Sample } \\
\text { Mean }(\mathrm{M})\end{array}$ & $\begin{array}{c}\text { Standard } \\
\text { Deviation } \\
(\text { STDEV })\end{array}$ & $\begin{array}{c}\text { T Statistics } \\
(\mid \text { O /STDEV } \mid)\end{array}$ & P Values \\
\hline $\mathrm{CAR} \rightarrow \mathrm{ROA}$ & 0241 & 0252 & 0102 & 2355 & $\mathbf{0 0 1 9}$ \\
$\mathrm{LDR} \rightarrow \mathrm{ROA}$ & -0098 & -0107 & 0086 & 1.145 & 0.253 \\
$\mathrm{CAR} * \mathrm{NPL} \rightarrow \mathrm{ROA}$ & 0.134 & 0.141 & 0.136 & 0.988 & 0.324 \\
$\mathrm{LDR} * \mathrm{NPL} \rightarrow \mathrm{ROA}$ & 0.030 & 0.041 & 0.108 & 0.279 & 0.781 \\
$\mathrm{NPL} \rightarrow \mathrm{ROA}$ & -0.163 & -0.162 & 0.099 & 1.655 & 0.099 \\
\hline
\end{tabular}

The results of the analysis in Table 10 can be explained as follows:

1. The first hypothesis is accepted because $\mathrm{X}_{1}$ (Capital Adequacy Level) to Y (Profitability) has a T-Statistics value $>1.96$, which is 2.355 , and a P-Values value $<0.05$, which is 0.019 . It can be interpreted that the Capital Adequacy Level has a significant effect on profitability.

2. The second hypothesis is rejected because $\mathrm{X}_{2}$ (Lending) to $\mathrm{Y}$ (Profitability) has a T-Statistics value $<1.96$, which is 1.149 , and a P-Values value $<0.05$, which is 0.253 . It means that Credit Distribution has no significant effect on profitability.

3. The third hypothesis is rejected because the interaction between $\mathrm{X}_{1}$ and $\mathrm{Z}$ (Capital Adequacy * Credit Quality) to Y (Profitability) has a T-Statistics value $<1.96$ and a P-Values $<0.05$, which is 0.324. Capital Adequacy Level with Credit Quality has no significant effect on profitability.

4. The fourth hypothesis is rejected because the interaction between $\mathrm{X}_{2}$ and $\mathrm{Z}$ (Credit Distribution*Credit Quality) to Y (Profitability) has a T-Statistics value $<1.96$ and a P-Values value $>0.0$. So it can be concluded that the interaction of Credit Distribution with Credit Quality has no significant effect on profitability.

\section{Discussion}

1. The Effect of Capital Adequacy Level on Profitability

Based on the results of data analysis in Table 10, it is concluded that the Capital Adequacy Level has a significant and positive effect on profitability. That means that when CAR increases, profitability will also increase. If the bank has enough capital, it can channel greater credit to its customers. The greater the credit disbursed, the greater the profit it will get. 
One of the important aspects of a bank's business unit is its capital adequacy, regardless of whether it operates or not or is trusted or not. The higher the capital of a bank, the higher the public trust to save their funds in the bank. This will have an impact on the increasing number of funds disbursed or profitability at the bank. CAR is a ratio that shows how far all bank assets contain risks (credit, investments, securities, claims on other banks). The risks are also financed from the bank's capital funds and obtaining funds from sources outside the bank, such as public funds and loans. (debt), and others. According to theory, the higher the CAR, the stronger the bank's ability to bear the risk of any risky credit/productive assets. The higher the CAR, the positive effect on profitability. Therefore, capital is an important factor in developing a bank's business. With sufficient capital, a bank can carry out its activities without experiencing difficulties and losses that may arise and then impact increasing profitability.

The capital adequacy ratio (CAR) is the capital adequacy ratio of banks and can affect the level of profitability of Islamic banks. There is a positive influence between the CAR ratio and bank profitability. That shows that the higher the CAR, the better the bank's ability to bear the risk of any risky earning assets. Previous research showed that Fitriana \& Oetomo (2016) results stated that the CAR ratio had a significant positive effect on profitability. And in line with research conducted by Anggraini et al. (2016)

The results of this study have a similar result with (Haneef et al., 2012), proving that the Capital Adequacy Level has a significant and significant effect on profitability. This result is also in line with research (Rosyid \& Irawan Noor, 2018), proving that the Capital Adequacy Level has a significant and significant effect on profitability. That means that the higher the Capital Adequacy Level, the higher the Profitability (Lall, 2014).

On the contrary, the results show a difference with (Boateng, 2018) that capital does not significantly affect profitability, which means the company is not motivated to increase its capital to show a good level of company capital adequacy. Similarities also appear with Agbeja et al. (2015; Oino, 2015), which state that capital has no significant effect on profitability. That is because high lending does not guarantee increased profitability (Prihartini \& Dana, 2018). Other researchers (Khrawish, 2011) explain that capital adequacy affects profitability. Meanwhile, according to (Rosyid \& Irawan Noor, 2018), CAR does no effect on return on assets (ROA).

2. The Effect of Credit Distribution on Profitability

Based on the results of data analysis in table 10, it can be concluded that Credit Distribution does not affect profitability. This study is in line with the research results (Charles \& Kenneth, 2013), showing that Credit Distribution does no effect on profitability. It is explained that the greater the disbursement of credit does not guarantee to increase profit or increase profitability because the amount of credit extended to customers regardless of the quality of the credit, the greater the possibility of bad loans that cause profit to decline. (Makkar \& Hardeep, 2018)

The banking sector can be one of the most flexible sectors in responding to national economic conditions compared to other economic sectors. So far, banks have committed to improving people's lives, but in practice, banks remain a business institution that seeks profit. The distribution of bank credit is significant. Through this, lending allows the public to carry out investment, distribution, and consumption activities that are always related to the use of money, thus driving the community's economic development. Banks act as an Agent of Development (Susilo, et al, 2000). Considering the culture of the Indonesians, which is very consumptive, lending is one of the alternatives that banks can do to take an active role in economic development.

Several studies showed that lending encourages a country's economic growth. Goldsmith (1969; Mckinnon, 1973; Shaw, 1973) stated that excess funds (surplus funds) channeled efficiently to units experiencing deficits would increase production activities. Furthermore, these activities will increase economic growth. At the micro-level, Gertler \& 
Gilchrist (1994) proved that obstacles in lending could impact the destruction of small businesses. Safe and productive credit positively impacts banks in terms of, firstly, increasing public confidence in banking, and secondly, maintaining profitability and business continuity.

The results of this study are not the same as the research presented by (Ramadan, 2011), which explains that LDR has a positive effect on Profitability (ROA). The study result (Lall, 2014) shows that credit distribution hurts profitability.

3. Effect of Capital Adequacy Level on Profitability with Credit Quality as Moderating Variable Based on the results of the Data analysis in Table 10, it can be seen that the interaction between Capital Adequacy Level and Credit Quality as measured by CAR*NPL can be seen in Table 10. That has a value original sample positive of 0.134 with T-statistic $0.988<1.96$ and P-value $0.324>0.05$; it can be seen that the interaction between Capital Adequacy Level and Credit Quality as a moderating variable has no significant effect on profitability.

Table 11. Results of Analysis of Types of Moderating Variables

\begin{tabular}{|c|c|c|}
\hline \multirow{2}{*}{$\begin{array}{l}\text { Interaction between } \\
\text { Moderator Variables and } \\
\text { Variables Predictor }\left(X^{*} \mathrm{Z}\right) \\
\text { There is no interaction }\end{array}$} & \multicolumn{2}{|c|}{$\begin{array}{c}\text { Relationship between Moderator Variables and } \\
\text { Variable Criteria } Y=f(x, Z)\end{array}$} \\
\hline & $\begin{array}{l}\text { There is a relationship } \\
\text { (1) }\end{array}$ & No relationship \\
\hline & $\begin{array}{l}\text { That variable is a variable: } \\
\text { Intervening, Exogenous, } \\
\text { Antecedent or predictor. }\end{array}$ & $\begin{array}{l}\text { That variable is a variable } \\
\text { Homologizer Moderator } \\
\text { (Potential Moderation) }\end{array}$ \\
\hline There is Interaction & $\begin{array}{l}\text { (3) } \\
\text { That variable is a variable: } \\
\text { Quasi Moderator }\end{array}$ & $\begin{array}{l}\text { (4) } \\
\text { That variable is a variable: Pure } \\
\text { moderator }\end{array}$ \\
\hline
\end{tabular}

Source: Sugiono, 2004

Table 11 explains that credit quality is a Moderator Homologiser model or Moderation Potential, which is a variable that has the potential to be a moderating variable but is not able to influence. Non-Performing Loans indicate that the higher the ratio value, the worse the credit quality, and cannot be moderated. In contrast, allowance for loan losses as part of net interest income is another measure of credit quality, indicating high credit quality by showing low numbers (Ginting, 2017). With a high level of capital adequacy, it tends to minimize lending to customers. Still, with a high level of capital adequacy that is not matched by high credit quality, the company will suffer losses for its problematic credit distribution or many bad credits (Alshatti, 2015).

This study aligns with the research result by (Rengasamy, 2014) which explains that credit quality does not affect profitability. This study is not in line with research (Oino, 2015) which explains that credit quality affects profitability.

4. The Effect of Credit Distribution on Profitability with Credit Quality as Moderating Variable As shown in Table 10, it can be seen that the interaction between Credit Distribution and Credit Quality as measured by LDR*NPL has a value original sample positive of 0.030 with T statistic $0.279<1.96$ and P-value $0.781>0.05$. The interaction between Credit Distribution and Credit Quality as a moderating variable has no significant effect on profitability. As described in Table 11, the results of this study include the Homologise Moderator Model or Potential Moderation, namely variables that have the potential or ability to become moderating variables but are unable to influence or are unable to moderate (Ghosh, 2015).

The more credit disbursed, the greater the profit (Gabriel et al., 2019). However, the higher the credit disbursement, the greater the possibility of bad or non-performing loans. That means that the size of a bank's profit is greatly influenced by the amount of credit disbursed in a period. 
In this study, credit quality is considered less capable of moderating credit distribution to profitability and established (Lartey et al., 2013). Management must determine how many credit targets must be disbursed each period. Management must also pay attention to credit quality; this is important because credit quality is related to the risk of congestion (problems) of a loan being disbursed.

The higher the quality of the credit provided, the less the risk of bad credit or nonperforming loans. It is known that the more bad debts, the lower the bank's profit. If not in target, the high level of credit disbursement, if not on target, can lead to a greater risk of bad loans, so that it will affect the interest income received (Oladele et al., 2012). This study has been proven by research conducted by (Langodai \& Lutfillah, 2019), explaining that credit quality cannot strengthen or weaken the effect of lending on Return On Assets. Research results In line with the results of research conducted (Gabriel et al., 2019).

\section{Theoretical Implication and Managerial Implication}

The theoretical implication in this study is that each moderator does not necessarily be a pure moderator, i.e., there can be an interaction between the dependent variable and the moderator variable. The managerial implication is that the desired credit quality will not necessarily increase profitability because many other factors affect the increase in profitability.

\section{Conclusion and Future Direction}

Based on this research, the credit quality variable cannot moderate the relationship between capital adequacy and credit distribution to profitability. The role of credit quality in research cannot be a pure moderator but only a Homologizer Moderator. Credit quality only has the potential to be moderate. This means that credit quality in this study only has the potential to be a moderator variable. For further research, it is necessary to try to add other independent variables so that they can be moderated by credit quality

\section{References}

Agbeja, O., Adelakun, O. J., \& Olufemi, F. I. (2015). Capital adequacy ratio and bank profitability in Indonesia: A linear approach. International Journal of Novel Research in Marketing Management and Economics, 11(5), 23-29.

Anggriani, M. D., Cipta, W., Yulianthini, N. N., \& SE, M. (2016). Pengaruh Capital Adequacy Ratio (CAR) Dan Non-Performing Loan (NPL) Terhadap Return on Assets (ROA) Pada Perusahaan Perbankan. Jurnal Manajemen Indonesia, 4(1).

Ali, Z., Gongbing, B., \& Mehreen, A. (2019). Supply chain network and information sharing effects of SMEs' credit quality on firm performance: Do strong tie and bridge tie matter? Journal of Enterprise Information Management, 32(5), 714-734.

Almazari, A. A. (2013). Capital Adequacy, Cost Income Ratio and the Performance of Saudi Banks (2007-2011). International Journal of Academic Research in Accounting, 3(4), 284-293.

Alshatti, A. S. (2015). The effect of the liquidity management on profitability in the Jordanian commercial banks. International Journal of Business and Management, 10(1), 62-72.

Andika., WIdya., Isti Fadah \& Puspitasari, Novi. (2018). Profitability Determinant of Conventional Commercial Banks using Credit Risk As a Moderating Variable. International Journal of Economics, Commerce and Research, 8(2), 23-30.

Bernardin, D. E. Y. (2016). Pengaruh CAR dan LDR terhadap Return on Assets. Jurnal Ecodemica: Jurnal Ekonomi, Manajemen, dan Bisnis, 4(2), 232-241.

Berrios, Myrna. (2013). The Relationship Between Bank Credit Risk And Profitability And Liquidity. The International Journal of Business and Finance Research, 7(3), 105-118. 
Boateng, K. (2018). Determinants of Bank Profitability: A Comparative Study of Indian and Ghanaian Banks. 5(5), 643-654.

Charles, O., \& Kenneth, O. (2013). Impact of credit risk management on the financial performance of commercial banks in Mauritius. Test Engineering and Management, 82(1-2), 546-559.

Corcoran, C. (2010). A Reassessment Of Regulated Bank Capital On Profitability And Risk. International Business \& Economics Research Journal (IBER), 9(3), 97-100.

Eniola, A. A., \& Ektebang, H. (2014). SME firms performance in Nigeria: Competitive advantage and its impact. International Journal of Research Studies in Management, 3(2), 75-86.

Faizah, Rahmawati Nur \& Saryadi (2018). Pengaruh Capital Adequacy Ratio (CAR), Loan To Deposit Ratio (LDR), Non-Performing Loan (NPL) Dan Net Interest Margin (Nim) Terhadap Return On Asset (Roa), Jurnal Ilmu Administrasi Bisnis, 7(3), 370-380.

Fitriana, E., \& Oetomo, H. W. (2016). Pengaruh NPF, CAR, dan EVA terhadap Profitabilitas Perusahaan Perbankan Syariah di BEI. Jurnal Ilmu dan Riset Manajemen (IIRM), 5(4), 1-16.

Gabriel, O., Victor, I. E., \& Innocent, I. O. (2019). Effect of Non-Performing Loans on the Financial Performance of Commercial Banks in Nigeria. American International Journal of Business and Management Studies, 1(2), 1-9.

Ghosh, A. (2015). Banking-industry specific and regional economic determinants of nonperforming loans: Evidence from US states. Journal of Financial Stability, 20, 93-104.

Ghozali, I., \& Latan, H. (2015). Partial Least Squares Concepts, Techniques and Applications using the SmartPLS 3.0 Program. Semarang: Issuing Board of Diponegoro University.

Gertler, Mark \& Gilchrist, Simon (1994). Monetary Policy, Business Cycles, anda The Behaviour of Small Manufacturing Firms. The quarterly Journal of Economics, 109(2), 309-340.

Ginting, D. (2017). Effect of Capital Adequacy Ratio (Car), Loan To Deposit Ratio (Ldr), Non Performing Loan $(\mathrm{Npl})$ and Operations Expenses To Operations Income (Bopo) on Return on Assets (Roa) At the Listed Banking Company in Indonesia Stock Exchange (Bei) Branch Batam. Jurnal Ilmiah Manajemen Universitas Putera Batam, 5(2), 231191.

Goldsmith, Raymond W. (1969), Financial Structure and Development, New Haven, CT; Yale University Press.

Haneef, S., Rana, M. A., \& Karim, Y. (2012). Impact of Risk Management on Non-Performing Loans and Profitability of Banking Sector of Pakistan Hailey College of Commerce University of the Punjab Hafiz Muhammad Ishaq Federal Urdu University of Arts, Science and Technology. International Journal of Business and Social Science, 3(7), 307-315.

Khrawish, H. A. (2011). Determinants of commercial banks performance: Evidence from Jordan. International Research Journal of Finance and Economics, 81(1), 148-159.

Lall, P. (2014). Factors affecting US banking performance: evidence from the 2007-2013 financial crisis. International Journal, 3(6), 282-295.

Langodai, D. J., \& Lutfillah, N. Q. (2019). the Influence of Third Party Funds, Capital Adequacy Ratio, Non Performing Loans To Credit Distribution on the Indonesia Stock Exchange. Research in Management and Accounting, 2(1), 14-25.

Lartey, V. C., Antwi, S., \& Boadi, E. K. (2013). The Relationship between Liquidity and Profitability of Listed Banks in Ghana. International Journal of Business and Social Science, 4(3), 48-56.

Mismiwati. (2016). Pengaruh Car, Nim, Bopo, Ldr Dan Npl Terhadap Roa (Studi Pada Pt. Bpd Sumsel Babel), I-FINANCE, 2(1), 55-74

Makkar, A. \& Hardeep (2018). Key factors influencing profitability of Indian commercial banks. International Journal of Academic Research and Development, 3(1), 373-378. 
Madugu, A. H., Ibrahim, M., \& Amoah, J. O. (2020). Differential effects of credit risk and capital adequacy ratio on profitability of the domestic banking sector in Ghana. Transnational Corporations Review, 12(1), 37-52.

McKinon, R.I. (1973). Money and Capital in Economic development, Washington, D.C: Brookings Institution

Nabellah, A. (2021). Effect of Capital Adequacy Level And Credit Distribution On Profitability With Credit Quality As Moderation Variables In Conventional Commercial Banks Listed On The Indonesian Stock Exchange. Researchjet Journal of Analysis and Inventions, 2(04), 3251.

Najjar, N. J. (2013). Can Financial Ratios Reliably Measure the Performance of Banks in Bahrain? International Journal of Economics and Finance, 5(3), 152-163.

Oino, I. (2015). Competitiveness and Determinants of Bank Profitability in Sub-Saharan Africa. International Journal of Economics and Finance, 7(10), 151-162.

Oladele, P. O., Sulaimon, A. A., \& Akeke, N. I. (2012). Determinants of bank performance in Nigeria. International Journal of Business and Management Tomorrow, 2(2), 1-4.

Olalekan, A., \& Adeyinka, S. (2013). Capital Adequacy and Banks' Profitability: an Empirical Evidence From Nigeria. American International Journal of Contemporary Research, 3(10), 87-93.

Prihartini, S., \& Dana, I. M. (2018). Pengarub CAR, NPL, Dan ROA Terbadap Penyaluran Kredit Usaba Rakyat (Studi Kasus pada PT Bank Rakyat Indonesia Tbk) (Doctoral dissertation, Udayana University).

Ramadan, I. Z. (2011). Bank-Specific Determinants Of Islamic Banks Profitability: An Empirical Study Of The Jordanian Market. International Journal of Academic Research, 3(6), 73-80.

Rengasamy, D. (2014). Impact of loan deposit ratio (LDR) on profitability: Panel evidence from commercial banks in Malaysia. International Conference on Global Economics, Finance and Social Sciences. 19th Dec 2014, Mumbai, India.

Rinawati, T. (2019). Kualitas Kredit Sebagai Pemoderasi Pengaruh Tingkat Permodalan Terhadap Profitabilitas Pada Perbankan Syariah. Bbm (Buletin Bisnis \& Manajemen), 5(1), 40-53.

Rosyid, P. I., \& Irawan Noor, M. (2018). Effect of Capital Adequacy Ratio (CAR), Loan to Deposit Ratio (LDR) and Return on Equity (ROE) on Share Price PT Bank Danamon Indonesia, Tbk. International Journal of Business and Applied Social Science (IJBASS), 4(1), 87-101.

Saona, P. (2011). Determinants of the Profitability of the US Banking Industry. International Journal of Business and Social Science, 2(22), 255-269.

Setiawan, A. (2017). Analisis pengaruh tingkat kesehatan bank terhadap Return on Asset. Jurnal Analisa Akuntansi dan Perpajakan, 1(2), 130-152.

Shaw. E.S. (1973). Financial Deepening in Economic Development, New York Oxford University Press.

Septiani, Rita \& Lestari, Putu (2016). Pengaruh Npl Dan Ldr Terhadap Profitabilitas Dengan Car Sebagai Variabel Mediasi Pada Pt Bpr Pasarraya Kuta, E-Jurnal Manajemen Unud, 5(1), 293 324

Shingjergii, A., \& Hyseni, M. (2015). The Determinants of the Capital Adequacy Ratio in the Albanian Banking System During 2007 - 2014. International Journal of Economics, Commerce and Management, 3(1), 1-10.

Suardita, I. W., \& Putri, I. (2015). Pengaruh Kecukupan Modal dan Penyaluran Kredit Pada Profitabilitas Dengan Pemoderasi Risiko Kredit. Fakultas Ekonomi Dan Bisnis Universitas Udayana. 
Santosa, Adi. (2016). Peningkatan Profitabilitas Pada Industri Perbankan Go-Publik di Indonesia, ESENSI: Jumal Bisnis dan Manajemen, 6(1), 1-16

Sugiyono. (2016). Metode Penelitian Kuantitatif, kualitatif dan R \& D. Alfabeta, Bandung.

Susilo, Y. S., Triandaru, S., \& Santoso, A. T. B. (2000). Bank dan Lembaga Kenangan Lain. Jakarta: Salemba Empat.

Yusuf, M., \& Surjaatmadja, S. (2018). Analysis of Financial Performance on Profitability with Non Performance Financing as Variable Moderation (Study at Sharia Commercial Bank in Indonesia Period 2012 - 2016). International Journal of Economics and Financial Issues, 8(4), 126132. 